\title{
At least three genes account for familial papillary thyroid carcinoma: TCO and MNG1 excluded as susceptibility loci from a large Tasmanian family
}

\author{
J D McKay ${ }^{1}$, J Williamson ${ }^{2}$, F Lesueur ${ }^{3}$, M Stark ${ }^{3}$, A Duffield ${ }^{1}$, F Canzian ${ }^{3}$, G Romeo ${ }^{3}$ and L Hoffman ${ }^{1}$ \\ Departments of ${ }^{1}$ Diabetes and Endocrinology, and ${ }^{2}$ Cytogenetics and Molecular Medicine, Royal Hobart Hospital, Tasmania, Australia and \\ ${ }^{3}$ Unit of Cancer Genetic Susceptibility, International Agency for Research on Cancer, Lyon, France \\ (Correspondence should be addressed to L Hoffman, Department of Diabetes and Endocrinology Services, Royal Hobart Hospital, Campbell St, Hobart, \\ Tasmania, Australia 7000)
}

\begin{abstract}
Recent studies have mapped two susceptibility loci which appear to account for familial multinodular goitre (MNG1) and a variant of familial papillary thyroid cancer (PTC), with associated multinodular goitre (TCO). A Tasmanian family (Tas1) has been identified with an autosomal dominant form of PTC.

This study has examined the MNG1 and TCO loci to determine if they are similarly predisposing the Tas1 family to PTC. Linkage analysis using identical microsatellite markers described in the two previous studies was used to determine the significance of these loci in the Tasmanian family. The resultant LOD scores were sufficiently negative using multipoint parametric analysis to exclude these two loci from involvement in the Tasmanian family.

In addition, six candidate genes, RET, TRK, MET, TSHR, APC and PTEN were also excluded as susceptibility genes in Tas1 by using microsatellites that are positioned in or in close proximity to these genes. These results suggest that there are at least three susceptibility genes that predispose families to familial PTC.
\end{abstract}

European Journal of Endocrinology 141 122-125

\section{Introduction}

Papillary thyroid cancer (PTC) is the most common form of thyroid carcinoma, accounting for over $85 \%$ of the lesions reported (1). There is increasing evidence that there is a familial component to PTC, with between $3.5-6.2 \%$ of PTC patients having one or more first degree relatives with thyroid carcinoma (2-6). Familial aggregations have been noted (7-9) and we reported the first recognised families predisposed to an autosomal dominant form of PTC with associated multinodular goitre (MNG) (10) (Fig. 1).

There are a number of candidate genes which may be involved in the development of familial PTC. These include: the MNG1 and TCO1 loci, two genes recently mapped to chromosomes $14 \mathrm{q} 31$ and $19 \mathrm{p} 13.2$ respectively, in familial non-medullary thyroid carcinoma families $(11,12)$, genes associated with the sporadic form of the cancer, the RET $(13-15), \operatorname{TRK}(16,17)$ and MET (18) tyrosine kinases, genes associated with familial syndromes with associated PTC, the APC and PTEN tumour suppressors associated with familial adenomatous polyposis coli $(19,20)$ and Cowden $(21)$ syndrome respectively and finally genes such as the TSHR which due to its function could be implicated in thyroid cancer, in addition to its proven involvement in other thyroid pathologies $(22,23)$.

We have used a large Tasmanian family (Tas1), identified by Burgess et al. (10), to determine the significance of the MNG1 and TCO loci and whether six possible candidate genes are predisposing this family to the PTC/MNG phenotype.

\section{Materials and methods}

\section{Patients}

The clinical and pathological features of two Tasmanian families with autosomal dominant PTC have been reported previously (10). The larger of the two families, Tas1, is displayed in Fig. 1, and represents the largest reported PTC family to date. Subsequent to the original report there has been one death in the proband due to metastatic thyroid cancer and one further patient diagnosed with thyroid cancer.

\section{Sample extraction}

Blood was collected from family individuals and all participants contributed with informed consent. DNA 


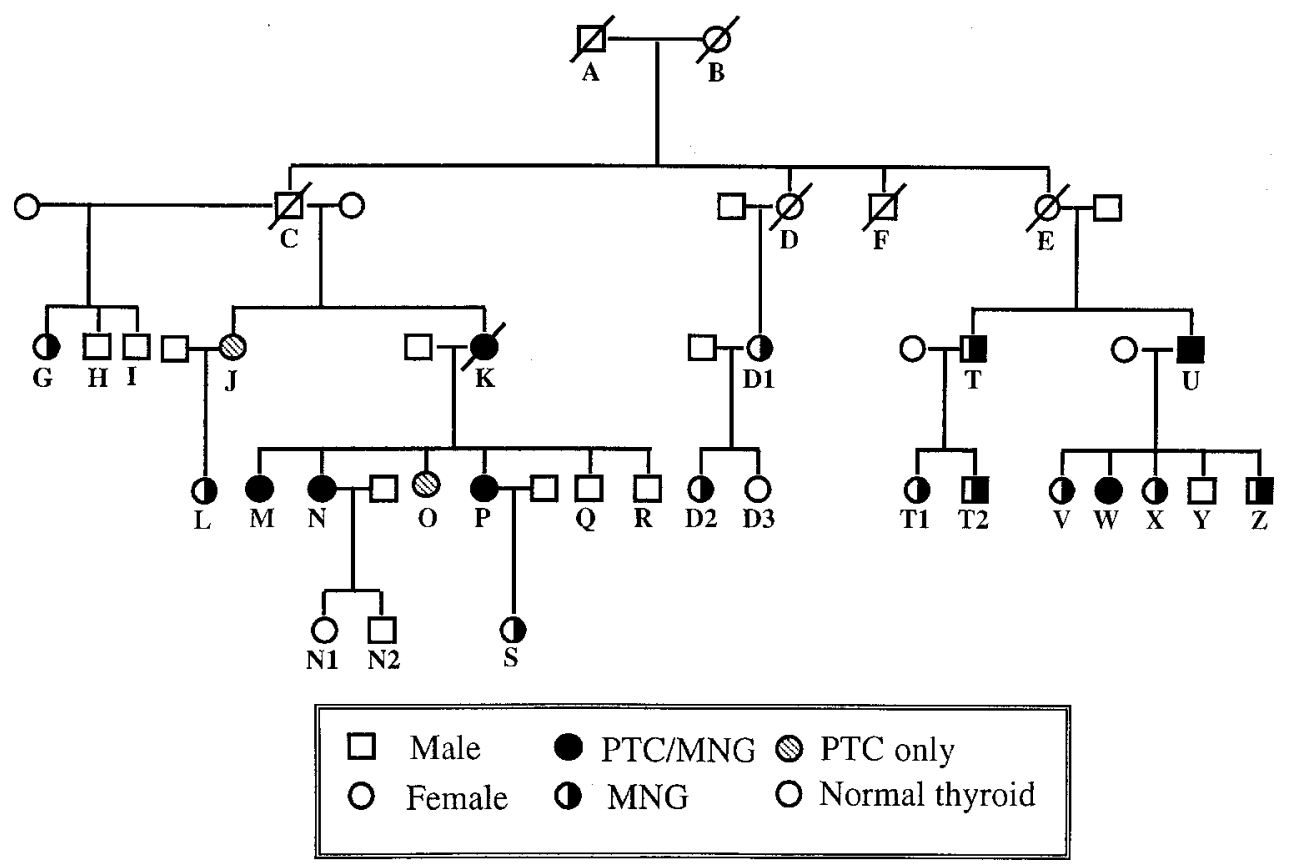

Figure 1 Tas 1 : the Tasmanian family with familial papillary thyroid cancer.

was extracted from the white blood cells using a cell lysis and precipitation method. DNA samples were stored at $-80{ }^{\circ} \mathrm{C}$ until use.

\section{Markers}

Microsatellite markers which were situated in or near the RET (sTCL2), TRK (D1S1595), MET (D7S2817), APC (D5S2501), PTEN (D10S541) and TSHR (D14S606) genes and linked markers in the MNG1 (D14S7495.0cM-D14S1030-0.1cM-D14S1054-2.7cM- D14S611) and TCO regions (D19S391-2.5cM-D19S916-1.1cMD19S413-0.6cM-D19S586) were used to genotype DNA from family members.

\section{Amplification}

Markers were amplified by PCR using fluorescent primers and standard PCR techiques (24). The fluorescent products were pooled and loaded onto a $4.8 \%$ polyacrylamide gel and run on a 377A ABI PRISM automated sequencer (Perkin-Elmer, ABI; Foster City, CA, USA). Data were automatically collected and analysed by the Genescan and Genotyper programs (Perkin-Elmer, ABI).

\section{Analysis}

Two-point linkage analysis was performed with the MLINK component of the LINKAGE program (25). Analysis was modelled using an autosomal dominant inheritance pattern with a disease allele frequency of
0.001 and a penetrance of 0.75. Multipoint analysis was performed with the Vitesse program (26) using the intervals between markers described earlier.

\section{Results}

Microsatellites located inside or in close proximity to eight candidate genes were used for linkage analysis. Loci in the MNG1 and TCO regions were examined for linkage in the Tasmanian family using multipoint analysis. The most informative marker for MNG1, D14S1030, produced a LOD (logarithm of the odds) score of -5.037 using multipoint analysis. Similarly, the LOD score at the TCO locus was -6.167 for the informative marker, D19S413, again indicating that this area is not linked in the Tasmanian family. Single point analysis was used with the remaining candidate genes. The LOD scores calculated were as follows: APC, $\mathrm{LOD}=-3.25(\theta=0)$, PTEN, $\mathrm{LOD}=-3.11 \quad(\theta=0)$, MET, $\quad \mathrm{LOD}=-4.94 \quad(\theta=0), \quad$ RET(sTCL-2), $\mathrm{LOD}=$ $-5.10(\theta=0), T R K, \mathrm{LOD}=-4.81(\theta=0)$ and TSHR, $\mathrm{LOD}=-3.32(\theta=0)$.

These negative results strongly suggest that there is no linkage between these loci and the familial PTC seen in the Tas1 family. Therefore, it is unlikely that the genes located in the immediate area of these microsatellites are susceptibility genes in the Tas1 familial PTC patients.

\section{Discussion}

Familial PTC is an established clinical entity, as demonstrated by clinical (9) and epidemiological (27) 
studies. The majority of pedigrees are small in size and a number do present with additional benign thyroid features of MNG (G Romeo et al., unpublished data). Larger families with many cases of non medullary thyroid cancer (NMTC) (papillary and follicular thyroid cancer) and MNG have been reported $(2,7,8,10)$. The two susceptibility loci mapped using two of these families, MNG1 (11) and TCO (12), are the only candidates that have been directly linked to familial NMTC and therefore were examined in the Tas1/PTC linkage study.

The negative linkage results found in this study allows for the exclusion of the MNG1 and TCO loci as susceptibility loci for PTC in the Tas1 family. This suggests that there is genetic heterogeneity in familial PTC/MNG and the existence of at least a third susceptibility gene. Further evidence for this finding is the existence of marked phenotypic differences between the three families. The Tas 1 family did not present with the distinct cell oxyphilia observed in the TCO family and had a much higher penetrance of PTC compared with the MNG1 family. In light of these marked differences between the phenotypes of the families, it is not surprising that there are different predisposing genes specific for each phenotype.

As a consequence of the exclusion of both the MNG1 and the TCO loci, a set of candidate genes was examined. The RET protooncogene is rearranged in a variable proportion of sporadic PTC tumours (13-15). In addition, RET mutations have been implicated in the development of familial multiple endocrine neoplasia (MEN) 2A of which medullary carcinoma of the thyroid (MTC) is the main manifestation (28) although MTC and PTC may be present (29). The association of mutations in RET with these diseases suggest it as a possible candidate for involvement in the development of familial PTC. However, this gene is not linked to PTC in the Tas 1 family and therefore mutations in this gene are unlikely to be a predisposing factor, a result which is in support of previous results reported for other PTC families (7). The remaining genes, TRK, MET, APC, PTEN and TSHR have been associated with sporadic and inherited thyroid pathologies including PTC to varying degrees (16-23). However, as in the case of RET, each of these genes was excluded as a candidate gene for PTC due to the lack of linkage, and therefore do not appear to be responsible for the development of familial PTC in the Tas1 family.

In conclusion, these results suggest that there are at least three genes that are responsible for familial MNG/ PTC/NMTC, with a possibility of each gene being specific for a phenotypic variant. The obvious next step is to begin a genome-wide search in order to find other genes involved in the development of this phenotype.

\section{Acknowledgements}

This work was funded by a Tasmanian Cancer Council research grant, and additionally supported by Electricite de France (contract RB97-06), l'Association pour la Recherche sur le Cancer (contract 4078-96), and the European Union (contract PL-962107). Fabienne Lesueur is a recipient of a Special Training Award from IARC. In addition, thanks must be extended to the members of the Tas 1 family for their precious collaboration.

\section{References}

1 Farid NR, Shi Y \& Zou M. Molecular basis of thyroid cancer. Endocrinology Review 199415 202-232.

2 Stoffer SS, Van Dyke DL, Vaden Bach J, Szpunar W \& Weiss L. Familial papillary carcinoma of the thyroid. American Journal of Medical Genetics 198625 775-782.

3 Hrafnkelsson J, Tulinius H, Jonasson JG, Olafsdoittir G \& Sigvaldason H. Papillary thyroid carcinoma in Iceland: a study of the occurrence of families and the coexistence of other primary tumours. Acta Oncology 198928 785-788.

4 Kwok CG \& McDougall IR. Familial differentiated carcinoma of the thyroid: report of five pairs of siblings. Thyroid 19955 395-397.

5 Galanti MR, Ekbom A \& Yuen J. Parental cancer and risk of papillary and follicular thyroid carcinoma. British Journal of Cancer 199775 451-456.

6 Austoni M. Thyroid papillary carcinoma in identical twins. The Lancet 1998141115.

7 Kraimps JL, Bouin-Pineau MH, Amati P, Mothes D, Bonneau D, Marechaud R \& Barbier J. Familial papillary carcinoma of the thyroid. Surgery $1997121715-718$.

8 Lote K, Andersen K, Nordal E \& Brennhovd IO. Familial occurrence of papillary thyroid carcinoma. Cancer 198046 1291-1297.

9 Grossman RF, Tu SH, Duh OY, Siperstein AE, Novosolov F \& Clark $\mathrm{OH}$. Familial nonmedullary thyroid cancer. Archives of Surgery $1995130892-899$.

10 Burgess JR, Duffield A, Wilkinson SJ, Ware R, Greenaway TM, Percival J \& Hoffman L. Two families with an autosomal dominant inheritance pattern for papillary carcinoma of the thyroid. Journal of Clinical Endocrinology and Metabolism 199782 345-348.

11 Bignell GR, Canzian F, Shayegi M, Stark M, Shuggart YY, Biggs P et al. Familial non toxic multinodular goitre locus maps to chromosome $14 \mathrm{q}$ but does not account for familial non medullary thyroid cancer. American Journal of Human Genetics 199761 1123-1130.

12 Canzian F, Amati P, Harach HR, Kraimps JL, Lesueur F, Barbier J et al. A gene predisposing to familial thyroid tumours with cell oxyphilia maps to chromosome 19p13.2. American Journal of Human Genetics 199863 1743-1748.

13 Grieco M, Santoro M, Berlingieri MT, Donghi R, Pierotti MA, Della Porta G et al. Molecular cloning of PTC, a new oncogene found activated in human thyroid papillary carcinomas and lymph node metastasis. Annals of the New York Academy of Sciences 1988551 380-381.

14 Bongarzone I, Butti MG, Coronelli S, Borrello MG, Santoro M, Mondellini $\mathrm{P}$ et al. Frequent activation of ret protooncogene by fusion with a new activating gene in papillary thyroid carcinomas. Cancer Research 199454 2979-2985.

15 Santoro M, Dathan NA, Berlingieri MT, Bongarzone I, Paulin C, Grieco M et al. Molecular characterisation of RET/PTC3; a novel rearranged version of the RET proto-oncogene in a human thyroid papillary carcinoma. Oncogene 19949 509-516.

16 Bongarzone I, Pierotti MA, Monzini N, Mondellini P, Manenti G, Donghi $\mathrm{R}$ et al. High frequency of activation of tyrosine kinase oncogenes in human papillary thyroid carcinoma. Oncogene 1989 4 1457-1462.

17 Martin-Zanca D, Hughes SH \& Barbacid M. A human oncogene formed by the fusion of truncated tropomyosin and protein tyrosine kinase sequences. Nature 1986319 743-748. 
18 Di Renzo MF, Olivero M, Ferro S, Prat M, Bongarzone I, Pilotti S et al. Overexpression of the c-MET/HGF receptor gene in human thyroid carcinomas. Oncogene 19927 2549-2453.

19 Cetta F, Chiappetta G, Marine Melillo R, Petracci, M, Mantalto G, Santoro $\mathrm{M}$ et al. The ret/ptc1 oncogene is activated in familial adenomatous polyposis-associated thyroid papillary carcinomas. Journal of Clinical Endocrinology and Metabolism 199883 10031006.

20 Harach HR, Williams GT \& Williams ED. Familial adenomatous polyposis associated thyroid carcinoma: a distinct type of follicular neoplasm. Histopathology 199425 549-561.

21 Lynch ED, Ostermeyer EA, Lee MK, Fernando Arena J, Ji H, Dann J et al. Inherited mutations in PTEN that are associated with breast cancer, Cowden's disease and juvenile polyposis. American Journal of Human Genetics 199761 1257-1260.

22 Russo D, Tumino S, Arturi F, Vigneri P, Grasso G, Pontecorvi A et al. Detection of an activating mutation of the thyrotropin receptor in a case of an autonomously hyperfunctioning insular carcinoma. Journal of Clinical Endocrinology and Metabolism 1997 82 735-738.

23 Parma J, Duprez L, Van Sande J, Cochaux P, Gervy C, Mockel J et al. Somatic mutations in the thyrotropin receptor gene cause hyperfunctioning thyroid adenomas. Nature $1993365649-651$.
24 Gyapay G, Morissette J, Vignal A, Dib C, Fizomes C, Millasseau P et al. The 1993-94 Genethon human genetic linkage map. Nature Genetics 199413 246-249.

25 Lathrop GM \& Lalouel JM. Easy calculation of lod scores and genetic risk on small computers. American Journal of Human Genetics $198436460-465$.

26 O'Connell JR \& Weeks DE. The VITESSE algorithm for rapid exact multilocus linkage analysis via genotype set-recoding and fuzzy inheritance. Nature Genetics 199511 402-408.

27 Goldgar DE, Easton DF, Cannon-Albright LA \& Skolnick MH. Systematic population-based assessment of cancer risk in firstdegree relatives of cancer probands. Journal of the National Cancer Institute 199486 1600-1608.

28 Mulligan LM, Kwok, JB, Healey C, Elsdon MJ, Eng C, Gardner E et al. Germ-line mutations of the RET proto-oncogene in multiple endocrine neoplasia type 2A. Nature 1993363 458-460.

29 Decker RA. Expression of papillary thyroid carcinoma in multiple endocrine neoplasia type 2A. Surgery 1993114 1053-1063.

Received 18 November 1998

Accepted 9 April 1999 